\title{
Nematode parasites of the Chilean Flamingo, Phoenicopterus chilensis (Phoenicopteridae) from Central Argentina, with a description of a new species of Tetrameres (Tetrameridae)
}

\author{
Verónica Núñez ${ }^{1,3 *}$, Fabiana B. Drago ${ }^{1,3}$, María Celina Digiani ${ }^{1,2}$ and Lia I. Lunaschii ${ }^{1,3}$ \\ ${ }^{1}$ División Zoología Invertebrados, Museo de La Plata, Facultad de Ciencias Naturales y Museo, Universidad Nacional de La Plata. \\ Paseo del Bosque S/N, 1900, La Plata, Buenos Aires, Argentina; ${ }^{2}$ CONICET, Godoy Cruz 2290, Cdad. Autónoma de Buenos Aires, \\ Argentina; ${ }^{3} \mathrm{CIC}$ Blas Parera 4035, Olivos, Buenos Aires, Argentyna
}

\begin{abstract}
During the summer of 2013, several specimens of Phoenicopterus chilensis (Phoenicopteridae) were found dead from unknown causes, in lakes from the endorheic system "Encadenadas del Oeste", Buenos Aires Province, Argentina. Two species of Nematoda were recovered from the proventriculus, one of them new for science. The tetramerid Tetrameres (Tetrameres) salina n. sp. is mainly characterized by having reduced pseudolabia, lips absent, six bifid teeth, males with lateral alae, four rows of somatic spines and length ratio of spicules 1:12-32, and large females with eggs lacking polar filaments. The acuariid, Echinuria skrjabinensis is described and illustrated, this finding represent the second report of this nematode in Argentina and the first record in flamingos. This is the first record of helminths parasitizing wild Chilean Flamingos, but it is not possible to ensure that they accomplish their life cycle in this system of lakes, because the migratory movements of the population of flamingos studied are unknown.
\end{abstract}

\section{Keywords}

Tetrameridae, Tetrameres (Tetrameres) salina n. sp., Acuariidae, Echinuria skrjabinensis, Phoenicopterus chilensis, Argentina

\section{Introduction}

Phoenicopterus chilensis Molina (Phoenicopteridae), commonly known as Chilean Flamingo, is an aquatic bird, distributed in coastal mudflats, estuaries, lagoons and salt lakes from sea level up to 4500 meters in altitude of Neotropical Region; from Central Peru southwards through Andes to Tierra del Fuego and extends eastwards to Uruguay and South Brazil (del Hoyo et al. 1992) Particularly, in Argentina has breeding population in the salt lagoons of Santa Fe, Buenos Aires and Cordoba Provinces; after the breeding season the flamingos move to unknown areas, some going eastwards towards the coastal salt/brackish lagoons of south Brazil, Uruguay and Argentina (Antas 1994). The diet of Chilean Flamingo consists mainly of aquatic invertebrates, including crustaceans (Artemia spp., copepods, cladocerans, ostracods and amphipods), larvae and pupae of Diptera (chironomids and brine flies), corixids, and snails (del Hoyo et al. 1992).
The helminth fauna of the Chilean Flamingo is scarcely known, to date it was only reported as host of two species of nematodes: Tetrameres sp. (Tetrameridae) and Streptocara incognita Gibson, 1968 (Acuariidae), both from birds in captivity conditions: from La Plata Zoological Garden, Argentina and from San Francisco Zoological Garden, USA, respectively (Boero and Led 1968, Fox et al. 1974).

The aim of this paper is to increase the knowledge of the diversity of helminths in flamingos from natural environments.

\section{Materials and Methods}

Between February and April 2013, an unspecified number of Phoenicopterus chilensis Molina (Phoenicopteridae) were found dead by unknown causes, on several lake shores from the endorheic system "Encadenadas del Oeste" in western Buenos Aires Province, Argentina. Seven of these birds were collected (six in Epecuén Lake, $37^{\circ} 13^{\prime} \mathrm{S}, 62^{\circ} 81^{\prime} \mathrm{W}$; and one in Del Monte 
Lake, $\left.36^{\circ} 59^{\prime} \mathrm{S}, 62^{\circ} 28^{\prime} \mathrm{W}\right)$, dissected in the field, their viscera were preserved in $10 \%$ formalin and transported to the laboratory for examination. Nematodes were removed from the proventriculus, preserved in $70 \%$ alcohol, and cleared by immersion in glycerine-alcohol for examination. Specimens for scanning electron microscopy (SEM) were dehydrated in an ethanol series, dried by the critical point technique, coated with gold, examined in a Jeol $6360 \mathrm{LV}$, and photographed. Measurements are given in micrometres $(\mu \mathrm{m})$ unless otherwise stated, as the range followed by the mean in parentheses. Drawings were made with the aid of a drawing tube. The helminths were deposited in the Helminthological Collection of the Museo de La Plata (MLP$\mathrm{He}$ ), and the hosts in the Ornithological Collection of the Museo de La Plata (MLP-Or 14259 - 14264), La Plata, Argentina.

\section{Description}

\section{Tetrameres (Tetrameres) salina n. sp. (Figs 1-4)}

Male (based on 11 specimens): Whitish worms. Cuticle with fine transverse striations from anterior to posterior extremities. Body elongated, tapering towards ends. Total length 4.12-5.26 (4.75) $\mathrm{mm}$. Maximum width 0.08-0.12 (0.1) $\mathrm{mm}$. Lateral alae extending in first quart of body (from behind amphids up to the last dorsal spines), then decreasing in size, even disappearing, reappearing at precloacal region and extending up to level of last lateral papillae (Figs 1a, 1c.). Cuticular spines in 4 rows; 1 dorsal and 1 ventral to each of lateral alae (Figs 1a, 2a). Dorsal rows occupying the first $20-25 \%$ of body, beginning at 26.3 from anterior end, with 24-33 spines, gradually increasing in size (from 3.7 to 13.1). Distance between spines variable along the row, from 13.3 to 44.6 . Ventral rows starting at 28.7 from anterior end, with about 50 spines, gradually increasing in size from 5.7 to 13.6 in the first quarter of body length. Posterior to this level, spines decreasing in size and spacing up to the distal quarter of body, where they become closer to each other and bigger as they approach the precloacal area. Mouth surrounded by two lateral trilobate pseudolabia, each one bearing three bifid teeth with sharp edges (Figs 1c, 2c). Dorsal and ventral lips absent. A single pair of large cephalic papillae at base of each pseudolabia, with the amphid outlet between them. Buccal capsule cylindrical (Fig. 2b), moderately sclerotized, 14-19 in depth (17.6) and 9.5-12 (10) of inner diameter. Oesophagus 1015-1392 (1145) long, about $24 \%$ of the body length, muscular portion $362-527.5$ (455), about $38 \%$ of oesophagus length, difficult to distinguish from glandular portion 637.5-1030 (774) long. Nerve ring at 186-221 (206) from the anterior end. Excretory pore not seen. Deirids short, spine like, arising from a slightly elevated circular base, situated approximately the level of the seventh pair of cuticular spines, 88-160 from the anterior end (128) (Fig. 1b). Spicules unequal (Fig. 2d). Right spicule slightly curved, 55-124 (87) long, with spatulate tip. Left spicule thin trough-shaped, 295-504 (425) long, 7-10\% (9\%) of body length, with spatulate tip, hilt 69-126 (93) long, representing $22 \%$ of entire spicule length. Length ratio of spicules 1:12-32 (1:23). Tail 143-266 (201) long, occupying 3 to $5 \%$ of body length and ending in a small conical mucron. Five pairs precloacal papillae and seven pairs postcloacal (four pairs ventral and three pairs lateral) (Figs 1d, 2d).

Female (based on 14 specimens): Gravid specimens, ellipsoidal to globular, with four deep longitudinal cuticular grooves along lateral and median fields and transverse striations only on the ends (Figs 3a, 4a), 3-4.2 (3.6) mm long by 2-3.2 (2.43) mm in maximum diameter, and 2.07-2.20 (2.11) $\mathrm{mm}$ in minimum diameter. Smooth cuticle, without alae, somatic papillae or spines. Much of the internal detail is obscured by the egg filled uterine coils surrounding a large saccular intestine. Anterior extremity 0.4-1.4 (0.64) mm long, includes muscular and proximal portion of glandular oesophagus (Fig. 4b). Four large submedian cephalic papillae and two lateral amphid outlets around the mouth. Oral opening circular, with hexagonal rim and six bifid blunt teeth (Fig. 3b). Buccal capsule rounded, well sclerotized, 19-26.2 (22.9) long by 16.7-21.4 (19.2) wide. Oesophagus 1758 - 1972 (1867) long, muscular portion 297.5366.5 (335) occupying 17-19\% of oesophagus length, glandular portion 1460-1605 (1533). Nerve-ring at 124-400 (209) from anterior end. Deirids and excretory pore not observed. Posterior extremity $0.08-0.6 \mathrm{~mm}(0.21)$ long, usually hidden between body folds due of excessive development of rest of body. Vulva and anus close to each other, and not always visible. Vulva inconspicuous at 350-362 (356) from posterior end. Tail short, broad and conical, 143-281 (211) long, with simple pointed tip. Eggs elongate, with near parallel sides, without polar filaments and containing fully developed larvae, 71-81 (76) long by 29-33 (31) wide (Fig. 4c).

\section{Taxonomic summary}

Type host: Phoenicopterus chilensis Molina (Phoenicopteridae), (Chilean Flamingo).

Site of infection: Proventriculus. Females within the glands, males free in the lumen.

Type locality: Epecuén Lake, Buenos Aires Province, Argentina $\left(37^{\circ} 13^{\prime} \mathrm{S}, 62^{\circ} 81^{\prime} \mathrm{W}\right)$.

Other locality: Del Monte Lake, Buenos Aires Province, Argentina $\left(36^{\circ} 59^{\prime} \mathrm{S}, 62^{\circ} 28^{\prime} \mathrm{W}\right)$.

Type material: Holotype (male) MLP-He 7254; allotype (female) MLP-He 7255; paratypes MLP-He 7256.

Voucher specimens: MLP-He 7257

Prevalence: 7 of $7(100 \%)$.

Mean intensity: 21.3 (range 11-73), females 18.7 (8-71), males $2.6(1-4)$.

Etymology: The specific name refers to the high salinity of the environment where the hosts were found.

\section{Remarks}

The cosmopolitan genus Tetrameres Creplin, 1846 consists of a group of nematode parasites of the proventriculus of aquatic birds, especially Anseriformes, Ardeiformes, Gruiformes and Charadriiformes, although some species are found in land birds 

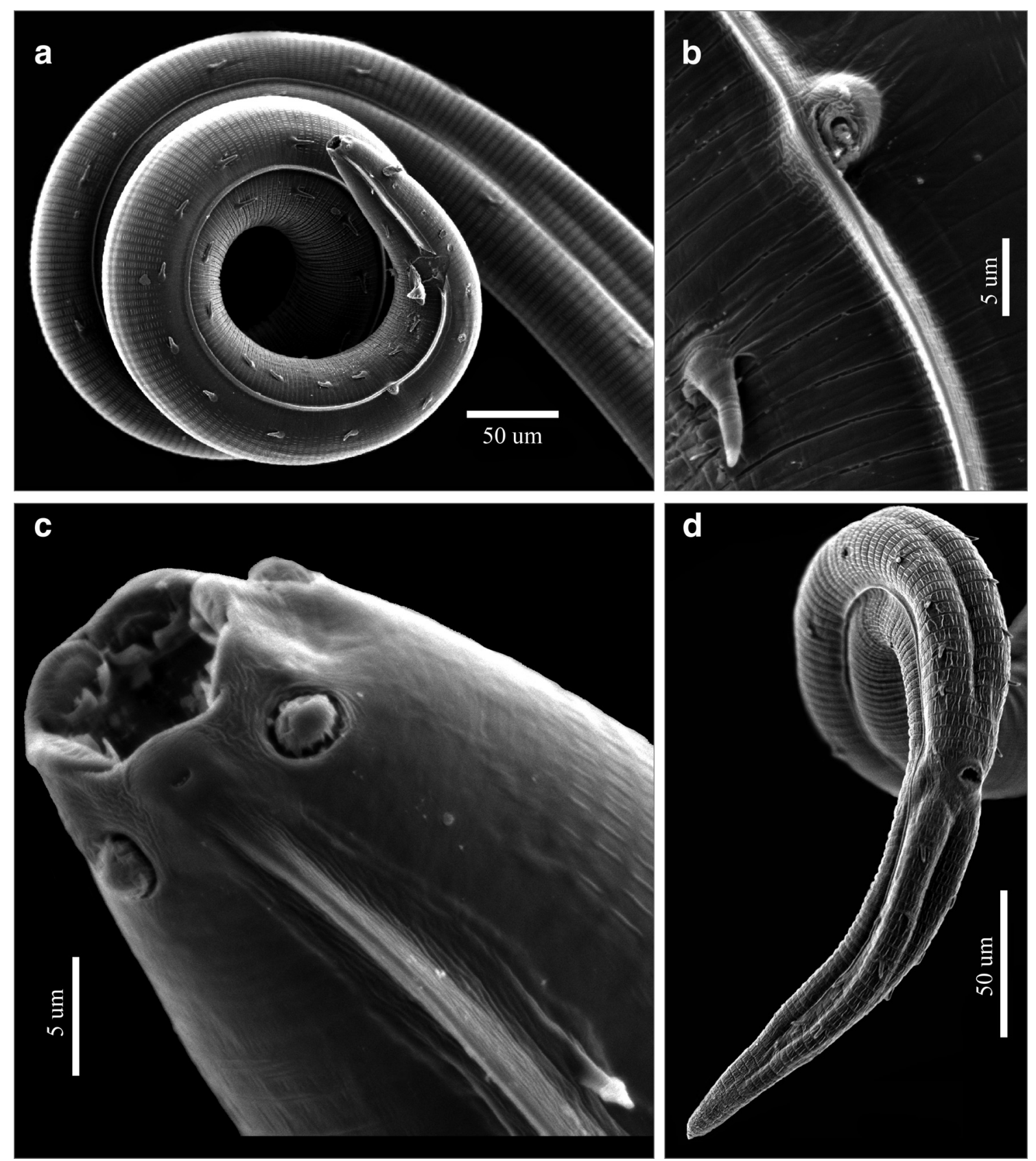

Fig. 1. Scanning electron micrographs of male of Tetrameres (Tetrameres) salina $\mathrm{n}$. sp. a - General anterior view. b - Deirid. c - Cephalic end. $\mathbf{d}$ - General posterior view

such as Passeriformes and occasionally Galliformes (Kinsella and Forrester 2008). Adult females permanently occupy the crypts of Lieberkühn, whereas the more typically nemaform males apparently move freely between the crypts and the lumen of proventriculus (Mollhagen 1991). In the present work we adopted the subgeneric arrangement of Mollhagen (1976), who recognized Tetrameres integrated by three subgenera, based primarily on oral structures and anterior cuticular formations: Tetrameres (Tetrameres) Creplin, 1846, distinguished by having reduced pseudolabia and without dorsal and ventral lips; Tetrameres (Gynaecophila) Gubanov, 1950 and Tetrameres
(Petrowimeres) Chertkova, 1953 characterized by possessing dorsal and ventral lips, and prominent lateral pseudolabia. In addition, T. (Petrowimeres) has distinctive anterior flanges originating from the bases of the pseudolabia and attached at the midline of the lateral somatic alae.

The specimens found parasitizing $P$. chilensis should be included in the subgenus Tetrameres (Tetrameres), in view of the presence of reduced pseudolabia and the absence of dorsal and ventral lips and anterior flanges originating from the bases of the pseudolabia. The main morphological characters used to distinguish the species are the number and arrange- 

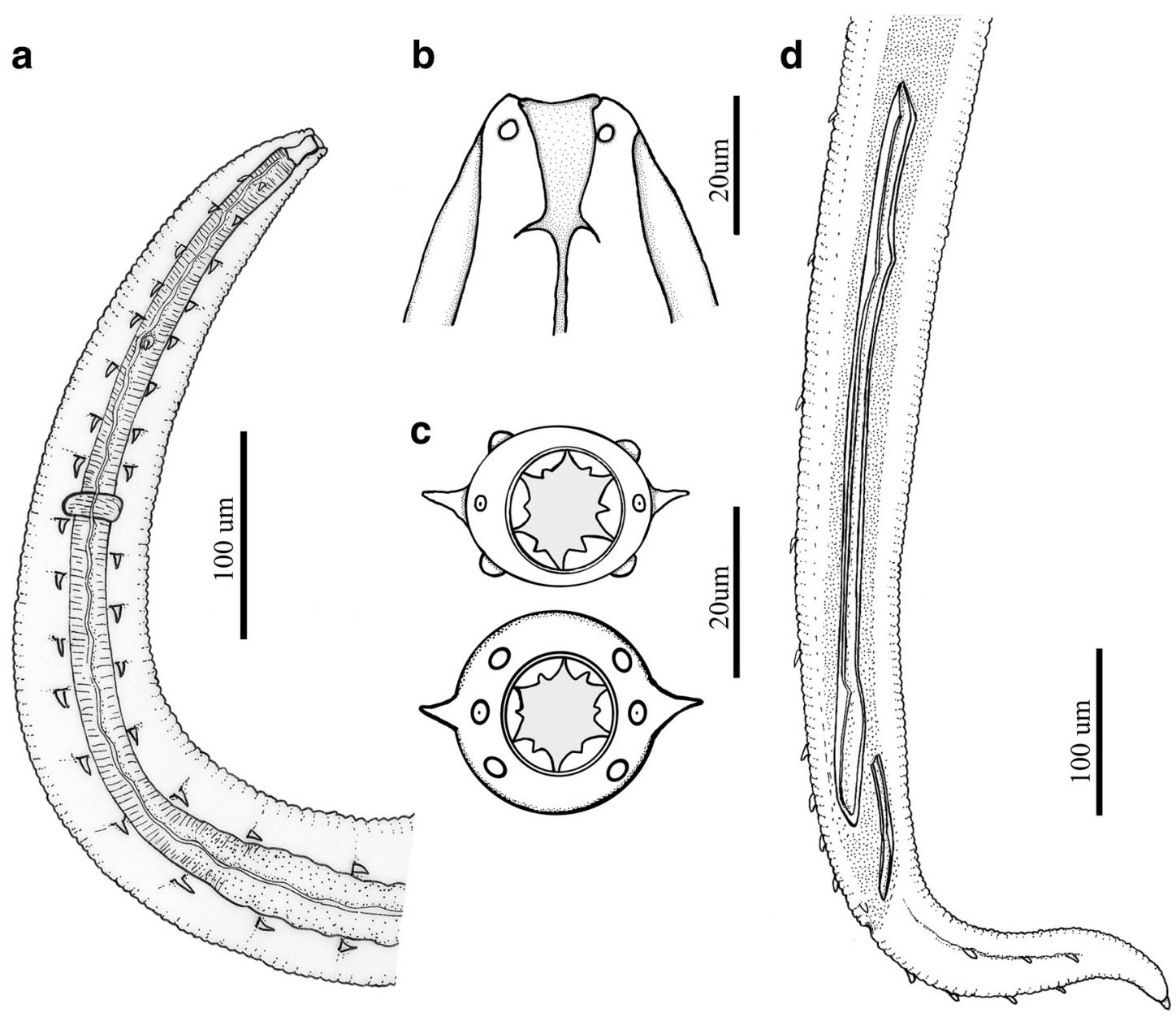

Fig. 2. Male of Tetrameres (Tetrameres) salina n. sp. a - General anterior view. b - Lateral view of cephalic end. c - Apical view of cephalic end. d-General posterior view

ment of somatic and caudal spines/papillae, number and shape of spicules, and spicule ratio.

The specimens here studied share the presence of four rows of spines /papillae with Tetrameres (Tetrameres) paradisea Ortlepp, 1932; Tetrameres (Tetrameres) megaphasmidiata Cremonte, Digiani, Bala et Navone, 2001 and the "nouveli" group of Mollhagen (1976).

Tetrameres (T.) paradisea (syn. Tetrameres grusi Shumakovich, 1946) was reported parasitizing Grus paradisea (Lichtenstein) (cited as Arthropoides paradisea) from South Africa; Grus grus (L.) from Asia; Grus monacha Temminck from Japan; Antigone canadensis (L.) (cited as Grus canadensis) and Grus americana (L.) from USA (Mollhagen 1976, Tuggle 1983, Gibson et al. 2005, Mowlavi et al. 2006). This species can be distinguished from $T$. (T.) salina n. sp. by having a lesser number of spines in the dorsal row (2-6 vs 24-33) and by possessing a pronounced and easily visible differentiation between muscular and glandular oesophagus.

Tetrameres (T.) megaphasmidiata described parasitizing charadriiform birds, Charadrius falklandicus Latham and
Calidris fuscicollis (Vieillot) from Argentina (Cremonte et al. 2001), mainly differs from the new species by possessing smaller males (1.94-2.03 $\mathrm{mm}$ vs $4.12-5.26 \mathrm{~mm}$ long) with a single spicule, large and conspicuous foliaceus phasmids and 8 pairs of postcloacal papillae (vs 7 pairs). In addition, the females and eggs are smaller (1.41-1.67 $\mathrm{mm}$ vs $3-4.2 \mathrm{~mm}$ long; 43-46 vs 71.4-80.9 long, respectively).

According Mollhagen (1976), the "nouveli" group is composed by five species: Tetrameres (Tetrameres) nouveli (Seurat, 1911); Tetrameres (Tetrameres) dubia Travassos, 1917; Tetrameres (Tetrameres) skrjabini Panova, 1926; Tetrameres (Tetrameres) prozeskyi (Ortlepp, 1961) and Tetrameres (Tetrameres) cladorhynchi Mawson, 1968. The specimens here studied possess several features that allow including them in the "nouveli" group of Mollhagen (1976), i.e. somatic spines arranged in four rows, two incomplete dorsal rows of many more than 6 spines in cervical region and two complete ventral rows, junction between muscular and glandular oesophagus difficult to distinguish, the former over $40 \%$ of the latter, and four subventral pairs and three sublateral pairs of postcloacal papillae. 

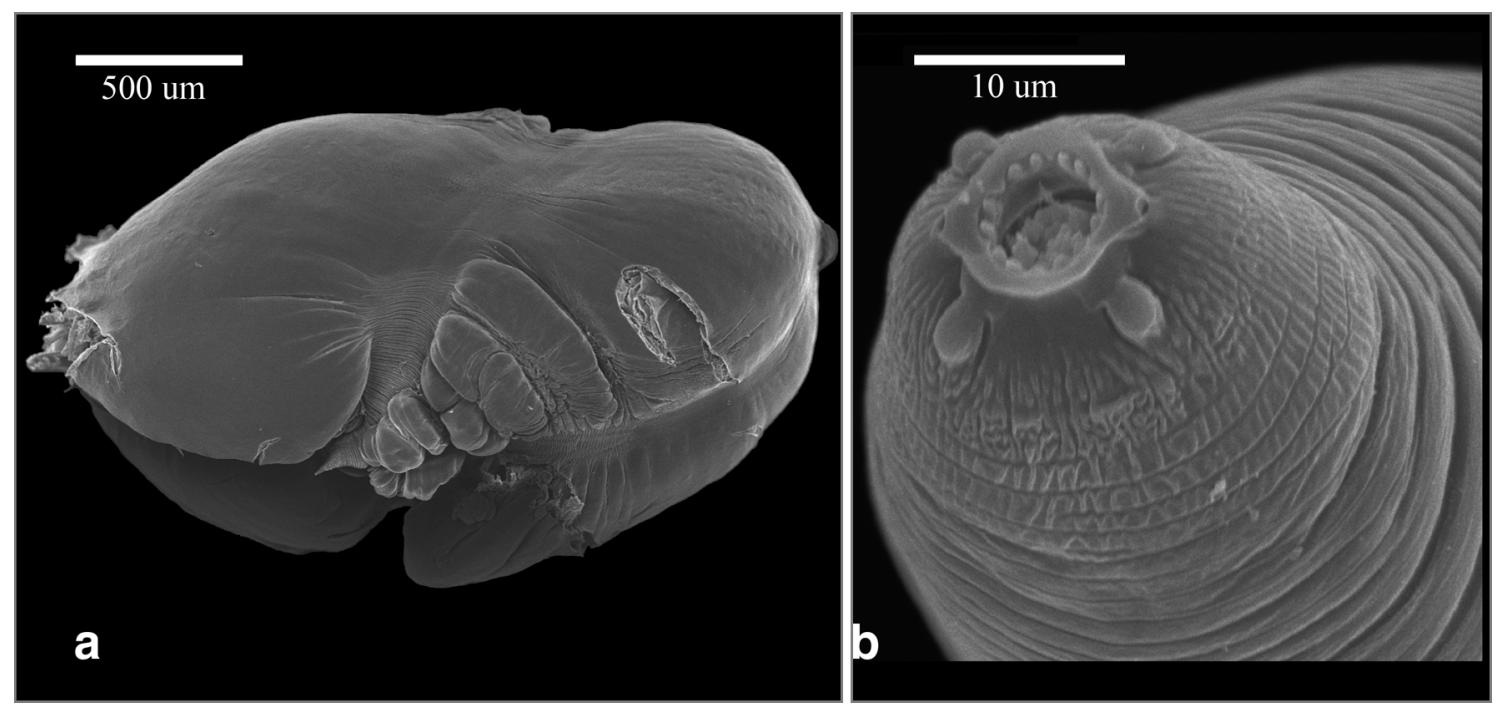

Fig. 3. Scanning electron micrographs of female of Tetrameres (Tetrameres) salina n. sp. a-General view. b-Cephalic end

Tetrameres (T.) cladorhynchi described parasitizing Cladorhynchus leucocephalus (Vieillot) (Charadriiformes) from Australia can be differentiated from the new species by smaller males (1.76-2.9 mm vs $4.12-5.26 \mathrm{~mm}$ long) with a single spicule, and longer left spicule (756-1370 vs 295-504 long).
Tetrameres (T.) dubia has been reported parasitizing a wide range of charadriiform birds from the Holarctic Region and Brazil (Mollhagen 1976, Gibson et al. 2005). This species can be differentiated from $T$. (T.) salina $\mathrm{n}$. sp. by smaller males (1.06-3.34 vs 4.12-5.26 mm long), without alae and longer left spicule (638-1209 vs 295-504 long). In addition, females
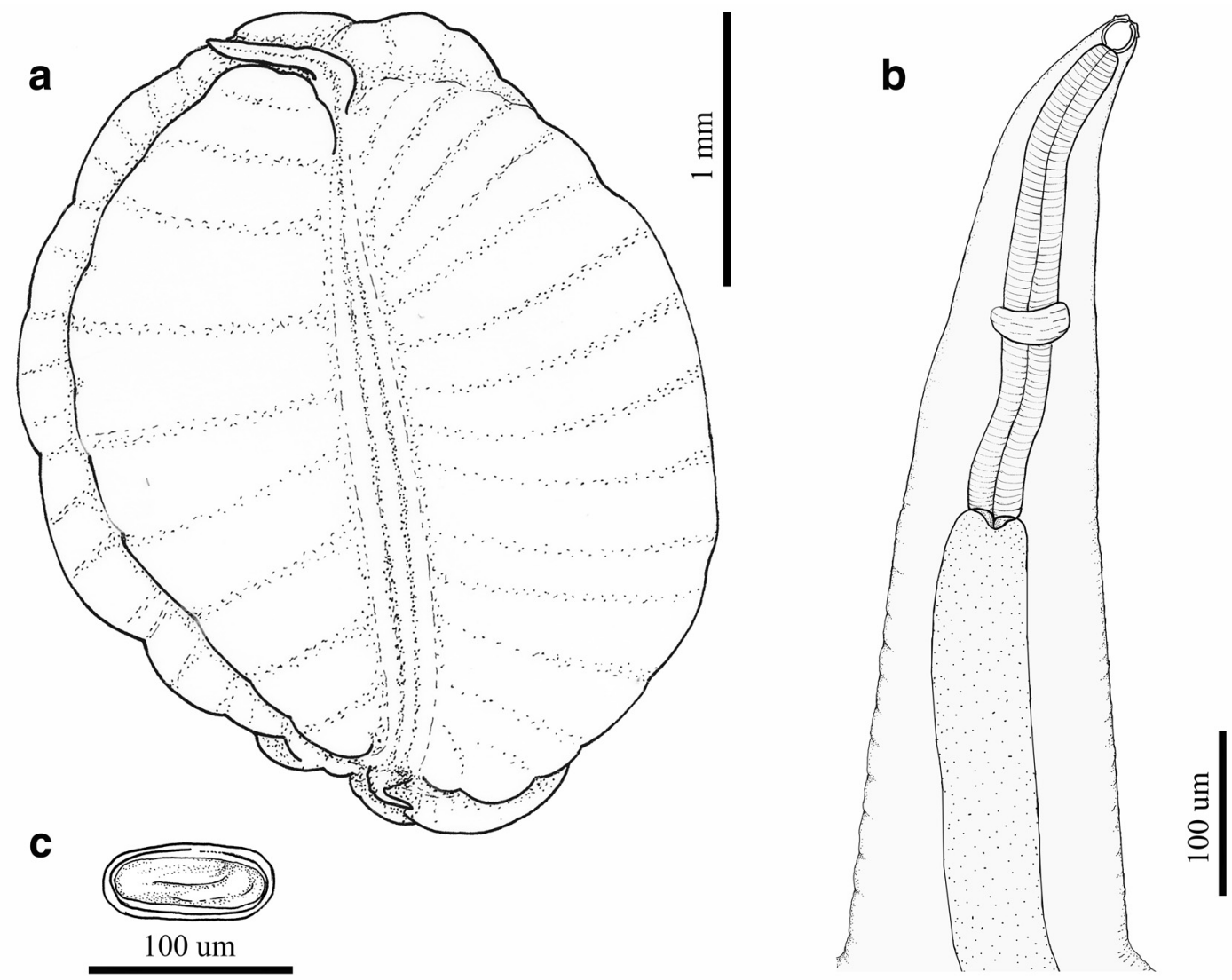

Fig. 4. Female of Tetrameres (Tetrameres) salina n. sp. a - General view. b - General anterior view. c - Egg 
are also smaller (1.68-2.50 $\mathrm{mm}$ long vs $3-4.2 \mathrm{~mm})$, have smaller eggs (47-50 vs 71-81) with polar filaments.

Tetrameres (T.) nouveli was reported in charadriiform birds, Charadrius alexandrinus L., Himantopus leucocephalus Gould and Recurvirostra novaehollandiae Vieillot from Australia, Charadrius wilsonia Ord from Cuba, Charadrius mongolus Pallas from Tadzhikistan, and Himantopus himantopus (L.) from Africa, Australia, Asia and Cuba (Mollhagen 1976, Gibson et al. 2005). This species differs from the new species by smaller males (1-2.4 vs $4.12-5.26 \mathrm{~mm}$ long) with left spicule rudimentary or absent. Females are also smaller (1.07$2.4 \mathrm{~mm}$ vs $3-4.2 \mathrm{~mm}$ long), and have smaller eggs (50-55 vs 71-81) with polar filaments.

Tetrameres (T.) prozeskyi, described parasitizing coraciiform birds, Tockus flavirostris (Rüppel) and Tockus erythrorhynchus (Temminck) from South Africa (Mollhagen 1976), differs from the new species by shorter males $(1.3-2.4 \mathrm{~mm}$ vs $4.12-5.26$ $\mathrm{mm}$ ) with a noticeable constriction just anterior to level of nerve ring, right spicule usually absent or, when present, longer (190220 vs 55-124), shorter left spicule (230-260 vs 295-504). In addition, females and eggs are also smaller $(1.8-2.26 \mathrm{~mm}$ vs 3-4.2 mm; 48-53 vs 71-81, respectively).

Tetrameres (T.) skrjabini reported in larid birds from Eurasia and North America (Mollhagen 1976, Gibson et al. 2005, Hervías Parejo et al. 2015), differs from T. (T.) salina $\mathrm{n}$. sp. by shorter males (2.76-3.25 vs 4.12-5.26), lateral alae absent or very weak, and longer left spicule (1370-1630 vs 295-504). In addition, females are shorter (1.37-1.63 vs 3-4.2), with lateral alae and smaller eggs (50-58 vs $71-81)$.

To date, only three species of Tetrameres have been reported in flamingos: Tetrameres coccinea (Seurat, 1914) in Phoenicopterus roseus Pallas from Asia and Africa (Yamaguti 1961) and Phoenicopterus ruber L. from Canada (Threlfall 1981); Tetrameres cubana Pérez Vigueras, 1941 in P. ruber from Cuba (Pérez Vigueras 1941); and Tetrameres sp. in P. chilensis from La Plata Zoological Garden, Argentina (Boero and Led 1968). These species remain unclassified at subgeneric level, because their descriptions lack details of the anterior end. The males of $T$. coccinea are unknown and the females differ from those of $T$. (T.) salina $\mathrm{n}$. sp. by being smaller $(2.2 \times 2.5 \mathrm{~mm}$ vs $3-4.2 \times 2-3.2 \mathrm{~mm})$, by the vulva situated at some distance of anus (480) vs vulva and anus close to each other, and by having smaller eggs (28-30 $\times 15-18$ vs $71-81 \times 29-33)$. Tetrameres cubana can be distinguished from the new species by the females with a shorter oesophagus (676 vs 1758), muscular portion occupying about $40 \%$ of oesophagus length vs $17-19 \%$, vulva situated at some distance of anus (354) vs vulva and anus close to each other, and smaller eggs $(53-60 \times 23-45$ vs $71-81 \times 29-33)$. The males differ by being smaller $(2.7 \times 0.12 \mathrm{~mm}$ vs 4.12 $5.26 \mathrm{~mm}$ ) and by having a shorter left spicule (220 vs 295 504). The specimens of Tetrameres sp. reported by Boero and Led (1968) in P. chilensis were not described; only a male and spicules were drawn without scale, and in this figure the cuticular spines are absent. Unfortunately, these specimens cannot be reviewed because no specimens were deposited at the appropriate time.

Based on all these morphological and morphometrical differences, a new species Tetrameres (Tetrameres) salina $\mathrm{n}$. sp. is proposed.

This is the fifth nominal species of Tetrameres reported from Argentina, the previous ones being Tetrameres (Tetrameres) tinamicola Pence, Mollhagen et Prestwood, 1975 in the tinamid, Eudromia elegans Geoffroy, Tetrameres (Gynaecophila) aspicula Digiani, 2000 and Tetrameres (Gynaecophila) spirospiculum Pinto et Vicente, 1995 in the threskiornithids Plegadis chihi (Vieillot) and Theristicus $m$. melanopis (Gmelin), respectively, plus the aforementioned $T$. (T.) megaphasmidiata in two species of charadriids (Pence et al. 1975, Digiani 2000, Digiani and Cremonte 2001, Cremonte et al. 2001).

\section{Echinuria skrjabinensis Efimov in Skrjabin, Sobolev et Ivashkin, 1965 (Fig. 5)}

Males (based on a young male enclosed in cuticle of fourth stage larva and posterior ends of two incomplete adults): In anterior part of body, cuticles of fourth stage larva and adult closely apposed; in median and posterior part, both cuticles loosely detached. On the larval cuticle, rows of spines and cordons present; tip of tail smooth, without projections. Body $3.30 \mathrm{~mm}$ long by $0.06 \mathrm{~mm}$. wide; cordons 205 long occupying $6.21 \%$ of body length. Buccal capsule 95 long; muscular oesophagus 230 long; glandular oesophagus 1020 long. Nerve ring, deirids and excretory pore not observed. Posterior region of body curved ventrally. Four pairs of pedunculated precloacal papillae grouped by two (pairs 1-2 and 3-4 very close together). Five pairs of postcloacal papillae, first and second pair pedunculated, close together and close posterior to cloaca; third pair pedunculated at some distance from first two; fourth and fifth pair, close together and near tip of tail, fourth pair shortly pedunculated, fifth pair sessile (Fig. 5a). Spicules dissimilar, left spicule slender 280-300 long $(n=3)$, with tip split into two branches, right one shorter and forked into two dissimilar points (Fig. 5b). Right spicule shorter and wider 105-115 long $(n=3)$, with a prominent triangular projection, subterminal, on the right edge (Fig. 5a). In young male spicules not completely sclerotized, caudal alae and papillae not developed.

Female (based on 10 specimens, of which 1 with eggs): Body 2.5-6.2 (4.0) $\mathrm{mm}$ long by 0.06-0.14 (0.09) $\mathrm{mm}$ wide; cordons 133-459 (280) long, occupying 4.9-10.5\% (7.25\%) of body length. One-sided ventral cuticular swelling well developed at the cephalic end (Fig 5c). Buccal capsule 87-165 (114) long; muscular oesophagus 186-379 (270) long; glandular oesophagus 832-1771 (1244) long. Nerve ring at 123155 (138) from anterior end. Deirids and excretory pore not 

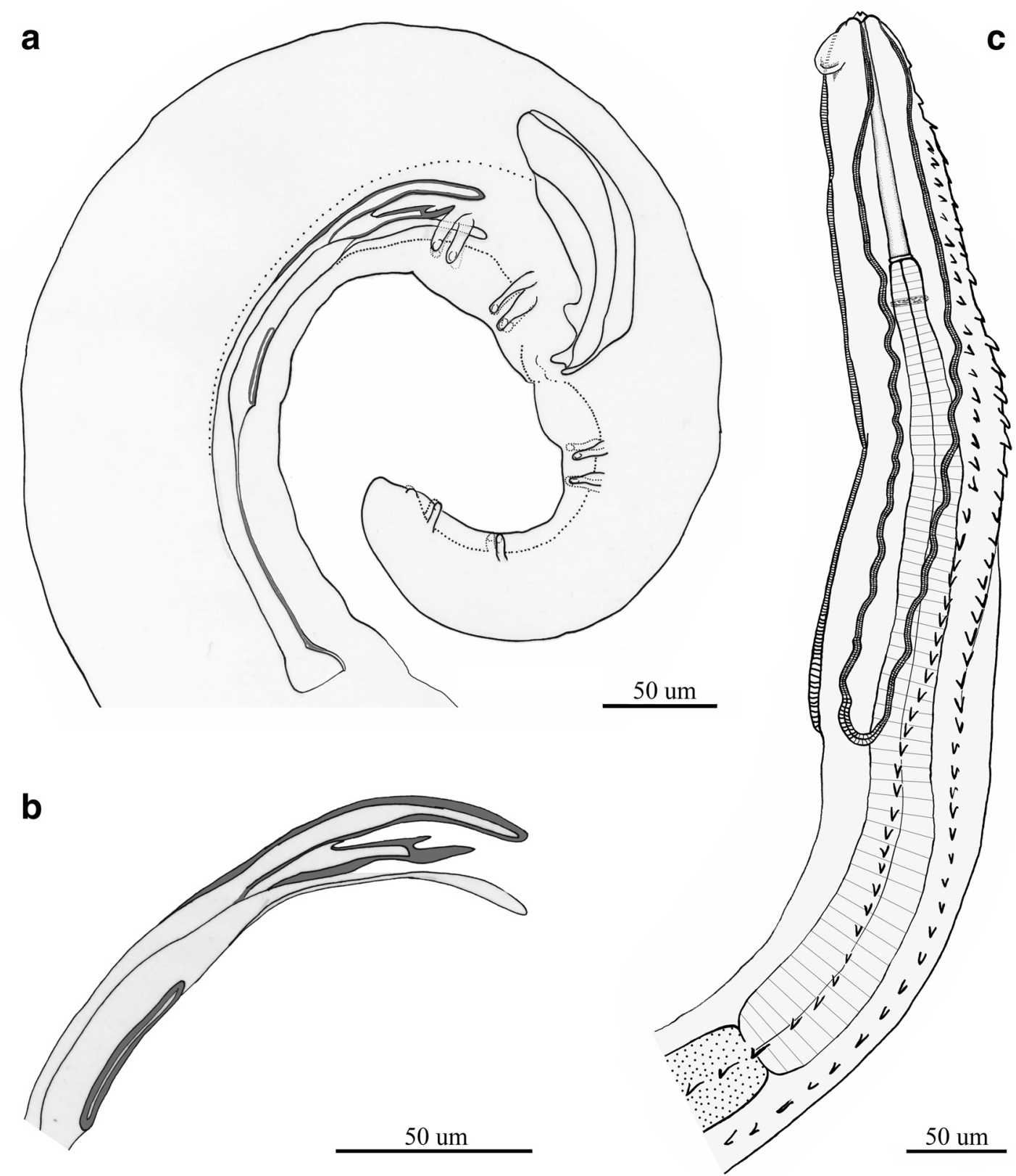

Fig. 5. Echinuria skrjabinensis. a - Male, lateral left view of posterior end. b-Detail of terminal end of left spicule. $\mathbf{c}-$ Female, anterior end, lateral left view

observed. Vulva in posterior region of body, at some distance from anus, and 503-1228 (824) from posterior end, located within distal $18-22 \%$ of body length. Tail 83-138 (106) long. In the single female with eggs in utero, eggs unembryonated and egg shell not completely developed.

Host: Phoenicopterus chilensis Molina (Phoenicopteridae), common name: Chilean Flamingo.

Site of infection: Proventriculus.

Locality: Epecuén Lake, Buenos Aires Province, Argentina $\left(37^{\circ} 13^{\prime} \mathrm{S}, 62^{\circ} 81^{\prime} \mathrm{W}\right)$.

Voucher specimens: MLP-He 7258

Prevalence: 3 of 7 (43\%).
Mean intensity: 5.5 (range 4-7), females 4.25 (3-6), males $1.67(1-2)$.

Distribution and hosts: This species has been cited parasitizing charadriiform birds, Recurvirostra avosetta L., Calidris minuta (Leisler), Calidris alba (Pallas), Calidris alpina L. and Calidris ferruginea (Pontoppidan) from Asia; Steganopus tricolor (Vieillot) and C. alpina from North America, and Calidris bairdii (Coues), and C. fuscicollis from Argentina (see Díaz et al. 2011).

Remarks: The males and females found parasitizing the Chilean Flamingo closely correspond morphologically and morphometrically to specimens of E. skrjabiniensis described 
by Sultanov et al. (1960) in Asia and also reported and described by Díaz et al. (2011) in Argentina. There are two main differences in our material with respect to this latter report: one is the presence of a cap surrounding the tip of the left spicule, reported by Díaz et al. (2011) but which could not be confirmed in our specimens. However the last authors stated that this structure was observed by some, but not all the authors reporting previously this species from different host and regions (see Díaz et al., 2011). The other difference is the number of distal postcloacal papillae, with 3 pairs reported by Díaz et al. (2011) near the tail tip and 2 pairs observed here. The description of Sultanov et al. (1960) also refers 2 distal pairs. In the present material, consisting of 2 posterior ends curved ventrally, a sixth pair of minute sessile papillae could be easily overlooked. However the pictures illustrating the 3 last pairs of papillae in the work by Díaz et al. (2011) do not distinguish clearly between the $5^{\text {th }}$ and $6^{\text {th }}$ pair, and a reasonable doubt could persist respect to the presence of 2 or 3 pairs of papillae in the distal group. On the contrary, the correct number of precoacal papillae is four pairs and not two (as described and illustrated Sultanov et al. 1960). These pairs being closely grouped by two transversally and not longitudinally (see Fig. 1F of Díaz et al. 2011 and Fig. 5a in this work), the internal pairs are likely to have been overlooked by Sultanov et al. (1960). The main morphological character allowing the assignation of these specimens to E. skrjabiniensis is the shape of the spicules, and particularly of the left spicule tip, split into two branches of which the right one is shorter and also forked into two dissimilar points, with the appearance of a seam ripper (Fig. 5b). Among the morphometrical characters, the total body length, length of cordons, ratio of cordon length on body length and position of the vulva are the most significant to distinguish this species from other species of Echinuria (see Díaz et al., 2011).

Only one species of Echinuria was reported parasitizing flamingos, Echinuria phoenicopteri (Seurat, 1916) described in P. roseus from Algeria, and based only on one juvenile female enclosed in the cuticle of the fourth stage larva. Seurat (1916) described the cuticle of the fourth stage larva as having cordons and four rows of spines on the anterior end, and the posterior end smooth and without projections, consistently with that observed in the young male present in our material. The measurements and proportions of the young female of Seurat (1916) are coincident with the lower values of our measurements range for females, which also correspond to young specimens. There is however, a difference in the arising of the rows of spines, which in E. phoenicopteri appear characteristically at two different levels: the laterodorsal rows arise at $60 \mu \mathrm{m}$. from the apex, whereas the lateroventral rows arise much more distally, at the level of anastomosis of the cordons (Seurat 1916). In conclusion, we attribute the specimens found parasitizing the Chilean flamingo to E. skrjabinensis due to the close similarity in both males and females. This finding constitutes the first report of E. skrjabiniensis parasitizing phoenicopteriform birds.

\section{Discussion}

The findings of T. (T.) salina $\mathrm{n}$. sp. and E. skrjabiniensis constitute the first record of helminths in wild populations of $P$. chilensis. Studies on wild populations of flamingos in Chile highlighted the absence of helminths (Gónzalez Acuña et al. 2001). There are only two records of helminths parasitizing Chilean Flamingos maintained under captivity conditions in Zoological Gardens, i.e. Tetrameres sp. and the acuariid, S. incognita (see Introduction).

The Epecuén Lake is eutrophic and hyperhaline (44.6-52.3 $\mathrm{g} / \mathrm{l}$ ), for this reason the hydrophytes are absent and the phytoplankton is represented by a dominant cyanobacteria, Coelosphaerium pallidum Lemmermann. The zooplankton is scarce, and represented by species indicative of high salinity: Artemia persimilis Piccinelli et Prosdocimi (Anostraca), Moina eugeniae Olivier (Cladocera) and Boeckella poopoensis Marsh (Copepoda). On the shores, there are shrimps, Palaemonetes argentinus Nobili. Also, a small fish, Jenynsia multidentata (Jenyns), was reported during periods of extraordinary floods (Calcagno et al. 1995, Miquelarena and López 1995, Schwerdt 2012). The Del Monte Lake is hypereutrophic and mesohaline (8.8-9.2 g/l), with abundant aquatic vegetation on coastal areas, mainly Schoenoplectus californicus (Meyer). The phytoplankton is represented mainly by the cyanobacteria, Microcystis pulverea (Wood); while the zooplankton is abundant with numerous species of rotiferans, cladocerans, copepods, ostracods and amphipods. Fishes are abundant, with ten species reported, including species commercially important as Odontesthes bonariensis (Valenciennes) (Calcagno et al. 1995, Schwerdt 2012).

The known life cycle of Tetrameres spp. parasites of waterfowl involve generally crustaceans (amphipods and cladocerans) as intermediate hosts, while in Echinuria spp. can intervene amphipods, cladocerans, isopods and ostracods (Anderson 2000). Recently, third-stage larvae of Acuariinae were found parasitizing Artemia franciscana Kellogg from Spain (Georgiev et al. 2014).

Despite the presence of crustaceans that can be involved as potential intermediate hosts of both species, it is not possible to ensure that they accomplish their life cycle in this system of lakes, because the migratory movements of the population of flamingos studied are unknown (Antas 1994). The first report of E. skrjabiniensis in the Southern Hemisphere was that of Díaz et al. (2011), who noted that the finding of adults and juveniles in migratory birds in Patagonia during the Austral summer could be an indication that the infections with this species were acquired in South America during the wintering period. The infection of the definitive hosts with this acuariid in the Southern Hemisphere seems confirmed with this finding of adults and juveniles in a new host just having limited dispersive movements between lakes outside the breeding season.

Prevalences and intensities of Tetrameres spp. tend to be higher in confined domestic birds than in wild populations (Kinsella and Forrester 2008), and Mollhagen (1976) stated 
that intensities of infections of Tetrameres spp. in wild birds usually average fewer than ten worms per bird, although intensities in the hundreds have been reported occasionally.

Pathogenicity of Tetrameres spp. varies among species, and also on the host resistance and intensity of infection. It can result in anemia and emaciation due to feeding on blood. Migration of the young parasites into the proventricular glands causes marked irritation and inflammation, which may cause the death of the birds (Kamil et al. 2011). Infections with Echinuria spp. can cause significant disease, particularly in birds experiencing stress by diminishing waters and scarce food, coupled with crowding around water bodies. These stress conditions could increase susceptibility to disease and allow greater accumulation of helminths (Work et al. 2004).

Acknowledgments. The authors express their gratitude to Cecilia Chiale and Luis Pagano by assistance in collecting the hosts, and to Florencia Fortini by their help in the helminthological prospection and screening. The present study was funded by CIC (Res. $\mathrm{N}^{\mathrm{o}}$ 833/14), UNLP (11/N 751) and CONICET (PIP 0006).

\section{References}

Anderson R.C. 2000. Nematode Parasites of Vertebrates: Their Development and Transmission. 2nd Edition. CABI Publishing, Wallingford, UK, pp. 650

Antas P.T.Z. 1994. Migration and other movements among the lower Parana River valley wetlands, Argentina, and the south Brazil/Pantanal wetlands. Bird Conservation International, 4, 181-190

Boero J.J., Led J.E. 1968. El parasitismo de la fauna autóctona. III. Los parásitos de las aves argentinas. Revista de la Facultad de Ciencias Veterinarias, La Plata, 10, 97-129

Calcagno A., Fioriti M.J., López H.L., Razquin M.E., Pedrozo F., Vigliano P., Rey C., Quirós R. 1995. Catálogo de lagos y embalses de la Argentina, Ministerio de Economía, Obras y Servicios Públicos, Secretaria de Obras Públicas, Subsecretaria de Recursos Hídricos, Buenos Aires, Argentina, pp. 61

Cremonte F., Digiani M.C., Bala L.O., Navone G.T. 2001. Tetrameres (Tetrameres) megaphasmidiata $\mathrm{n}$. sp. (Nematoda: Tetrameridae), a parasite of the two-banded plover, Charadrius falklandicus, and white-rumped sandpiper, Calidris fuscicollis, from Patagonia, Argentina. Journal of Parasitology, 87, 148151. DOI: $10.1645 / 0022-3395$.

del Hoyo J.C. 1992. Family Phoenicopteridae. In: (Eds. J. del Hoyo, A. Elliott and J. Sargatal). Handbook of the Birds of the World. Vol. 1, Lynx Edicions, Barcelona, 536-628

Díaz J.I., Panisse G., Escudero G., Kinsella J.M. 2011. New host and geographical records and morphological details for Echinuria skrjabiniensis (Nematoda, Acuariidae) from shorebirds in Argentina. Acta Parasitologica, 56, 315-319. DOI: 10.2478/s11686-011-0063-5

Digiani M.C. 2000. Tetrameres (Gynaecophila) aspicula n. sp. (Nematoda: Tetrameridae), a proventricular parasite of the white-faced ibis Plegadis chihi in Argentina. Systematic Parasitology 47, 111-117

Digiani M.C., Cremonte F. 2001. New host and locality records for Tetrameres(Gynaecophila) spirospiculum Pinto \& Vicente, 1995 (Nematoda: Tetrameridae), with new morphological data. Memórias do Instituto Oswaldo Cruz, 96, 339-341
Fox J.G., Snyder S.B., Schmidt G.D., Campbell L.H. 1974. Infection with the nematode Streptocara incognita in the Chilean Flamingo. Journal of Wildlife Diseases, 10, 66-69. DOI: 10.7589/0090-3558-10.1.66

Georgiev B.B., Angelov A., Vasileva G.P., Sánchez M.I., Hortas F., Mutafchiev Y., Pankov P., Green A.J. 2014. Larval helminths in the invasive American brine shrimp Artemia franciscana throughout its annual cycle. Acta Parasitologica, 59, 380389. DOI: $10.2478 / \mathrm{s} 11686-014-0255-\mathrm{x}$

Gibson D.I., Bray R.A., Harris E.A. (Compilers) 2005. Host-Parasite Database of the Natural History Museum, London. URL. http://www.nhm.ac.uk/research-curation/scientificresources/taxonomy-systematics/host-parasites/

Gónzalez Acuña D., Martínez Inostrosa A., Brevis Ibáñez C., Rubilar Contreras L., Galaz Leigh J. 2001. Ausencia de parásitos gastrointestinales en Flamencos Chilenos (Phoenicopterus chilensis Molina, 1782) juveniles en el Salar de Surire. Boletín Chileno de Ornitología, 8, 27-30

Hervías Parejo S., Martínez-Carrasco C., Diaz J.I., Chitimia L., Ortiz J., Mayo E., Ruiz de Ybáñez R. 2015. Parasitic fauna of a yellow-legged gull colony in the island of Escom breras (South-eastern Mediterranean) in close proximity to a landfill site: potential effects on cohabiting species. Acta Parasitologica, 60, 290-297. DOI: 10.1515/ap-2015-0041

Kamil S.A., Darzi M.M., Mir, M.S., Shah, S.A., Shah, S.N., Khan, F.A. 2011. Tetrameres fissispina infection in ducks from Bandipora area of Kashmir Valley. Israel Journal of Veterinary Medicine, 66, 43-47

Kinsella J.M., Forrester D.J. 2008. Tetrameridosis. In: (Eds. C.T Atkinson, N.J Thomas. and B. Hunter) Parasitic diseases of wild birds. Willey Blackwell, Iowa, 376-383

Miquelarena A.M., López H.L. 1995. Fishes of the lagunas Encadenadas (Province of Buenos Aires, Argentine) a wetland of international importance. Freshwater Forum, 5, 48-53

Mollhagen T.R. 1976. A study of the systematics and hosts of the parasitic nematode genus Tetrameres (Habronematoidea: Tetrameridae). PhD. Thesis. Texas Tech University, Lubbock, Texas, USA, 545

Mollhagen T.R. 1991 A study of the parasitic nematode genus Tetrameres. I. The literature, 1835-1985. Special Publications, The Museum, Texas Tech University, 35, 1-76.

Mowlavi G.R, Massoud J., Mobedi, I., Gharagozlou M.J., Rezaian, M., Solaymani-Mohammadi S. 2006. Tetrameres (Tetrameres) grusi (Shumakovich, 1946) (Nematoda: Tetrameridae) in Eurasian Cranes (Grus grus) in Central Iran. Journal of Wildlife Diseases, 42, 397-401. DOI: 10.7589/0090-355842.2.397

Pence D.B, Mollhagen T.R., Prestwood A.K. 1975. Tetrameres (Tetrameres) tinamicola sp. n. from the crested tinamou, Eudromia elegans, with comments on the subgenus Petrowimeres (Nematoda: Tetrameridae). Journal of Parasitology, $61,825-829$

Pérez Vigueras I. 1941. Nota sobre varios vermes encontrados en el "flamenco" (Phoenicopterus ruber). Memorias de la Sociedad Cubana de Historia Natural, 15, 327-336

Schwerdt M.G. 2012. Estructura, composición y dinámica estacional de las comunidades de peces del sistema de las lagunas encadenadas del oeste, provincia de Buenos Aires. PhD Thesis, Universidad Nacional del Sur, Bahía Blanca, Buenos Aires, Argentina

Seurat L.G. 1916. Sur la quatrième mue d'un dispharage du flammant. Comptes rendus des séances de la Société de biologie et de ses filiales. 79 (10): 439-441

Sultanov M.A., Ryzhikov K.M., Kozlov D.P. 1960. On the nematode fauna of wild birds from the mouth of the Amu-Darya. Uzbekskiy Biologicheskiy Zhurnal, 1, 58-63 (In Russian) 
Threlfall W. 1981. Helminth Parasites of an American Flamingo from Newfoundland. Proceedings of the Helminthological Society of Washington, 48, 89-90

Tuggle B. N. 1983. Tetrameres grusi (Nematoda: Tetrameridae) from foster-raised Whooping Crane. Proceedings of the Helminthological Society of Washington, 50, 332

Work T.M., Meteyer C.U., Cole R.A. 2004. Mortality in Laysan Ducks (Anas laysanensis) by emaciation complicated by Echinuria uncinata on Laysan Island, Hawaii, 1993. Journal of Wildlife Diseases, 40, 110-114. DOI: 10.7589/0090$3558-40.1 .110$

Received: June 29, 2016

Revised: January 25, 2017

Accepted for publication: February 20, 2017
Yamaguti S. 1961. Systema Helminthum, Vol. III. The Nematodes of Vertebrates, Part. I and II. Interscience Publishers, New York \& London, pp. 1261 